\title{
The Effect of Religiosity on Poor Adult Woman's Meaningfulness of Life
}

\author{
Alif Muarifah, Siti Muyana*, Hudzaimah Nur Hidayah \\ Universitas Ahmad Dahlan Yogyakarta, Indonesia \\ ⓘti.muyana@bk.uad.ac.id*
}

\section{Article Information:}

Received October 19, 2019

Revised November 16, 2019

Accepted April 29, 2020

Keywords: meaningfulness; poor adult woman; religiosity

\begin{abstract}
Having a meaningful life is a part of a happy, vigorous, anxiety-free life. Various factors, such as poverty and religiosity, may affect an individual's meaningfulness of life. Grounded from the phenomenon, the present study aims to find out the effect of poor adult women's religiosity on the meaningfulness of life. The samples of the study were 123 women who were selected using cluster random sampling. The selected samples were women who met the criteria of "poor" according to the National Family Planning Coordination Board of the Republic of Indonesia (BKKBN RI), which is categorized as prosperous family 1 . This study used meaningfulness of life scale and religiosity scale authors had developed. The data were analyzed using simple linear regression. The result showed that religiosity significantly affects the meaningfulness of life ( $F=55.659$, $p<0.005)$, meaning that the higher the religiosity, the higher the meaningfulness of life. The result of the study may provide a depiction of the effect of poor adult woman's religiosity on the meaningfulness of life, which can be used as a reference for the government or community observer on how to make a meaningful life by strengthening the religiosity.
\end{abstract}

\section{INTRODUCTION}

Meaningfulness is one of the most basic human needs to be motivated in achieving life goals. Accordingly, it is important to have a meaningful life to understand how to live a purposeful life. According to Bastaman (2007), meaningful life refers to a happy, passioned, anxiety-free life. Meaning in life is one of the sources of spirit for an individual to live his/her life. The finding of the study conducted by Arista (2017) exhibited that in order to obtain meaningfulness of life, some phases can be done. Starting from the phase of misery, selfacceptance, meaningfulness of life discovery, meaning realization, to meaningful internalization (happiness) phase. Individuals who fail to obtain meaningfulness of life may be at risk of living a meaningless life.

Meaningless life may result in various adverse effects such as anxiety, boredom, despair, and even thought of suicide. One of the real examples showing that individuals live a meaningless life is suicide due to various factors, such as poverty. Poverty often emerges as one of the causes of conflict because it makes individuals feel meaningless, thus making them to lose their life hope. According to Bastaman (2007) an individual's low life hope and meaning may lead to anxiety, despair, and apathy. Life hope means the presence of belief that better changes will take place, patience in facing current bad conditions, and optimism in facing the future. Life hope stated by Bustanun begins by meaningfulness is human's most basic desire (Listiari, 2016). Accordingly, meaningfulness of life is important in order to attain valuable, frustration-free life.

$\begin{array}{ll}\text { How to cite: } & \begin{array}{l}\text { Muarifah, A., Muyana, S., \& Hidayah, H. (2020). The Effect of Religiosity on Poor Adult Woman's } \\ \text { Meaningfulness of Life. Islamic Guidance and Counseling } \\ \text { https://doi.org/10.25217/igcj.v3i2.569 }\end{array} \\ \text { E-ISSN: } & 2614-1566 \\ \text { Published by: } & \text { Institut Agama Islam Ma'arif NU (IAIMNU) Metro Lampung }\end{array}$


Based on the preliminary study conducted by Hudzaimah (2019) on 6 April 2018 in Gari village on ten poor adult women, $60 \%$ of them have low meaningfulness of life. Their low level of meaningfulness of life was characterized by low level of freedom to do and to have what they want, feeling that their life is stuck, giving up on the condition, unclear purpose in life, and lack of satisfaction. In addition, conflict and social jealousy result in despair and succumbing, which makes them feel meaningless life. The study conducted by Hayyu \& Mulyana (2015) depicts that sadness, boredom, shyness, inferiority, and thought of suicide indicate low meaningfulness of life.

In fact, meaningfulness of life may be affected by various factors, which can be categorized into internal and external factors (Bastaman, 2007). Internal factors include selfdiscovery, positive behavior, environmental familiarity, the deepening of three values, prayer, personal quality, while the external factors include material, social support, job, and close persons. Both factors affect an individual's meaningfulness of life. Prayer is one of the internal factors stemming from religiosity. Religiosity and religion are often viewed as the same, whereas they are different, yet complement each other. Religiosity is one of the important things within an individual. Religiosity is associated with one's belief in God or other religious matters.

Prasetyoningrum (2012) states that religiosity leads to the quality of life attitude and internalization based on religious values, it emphasizes more on religious noble values and tends to avoid religious formalism. According to Reza (2015), religiosity deals with the width of knowledge, the strength of a belief, the implementation of pray. In other words, religiosity constitutes an individual's knowledge, belief, and adherence in carrying out his/her responsibility as a believer. The result of interviews conducted on 6 April 2018 with poor inhabitants in Gari Village about religiosity found that out of ten subjects, 5 participants stated that they did not know much about religion, felt that their prayer had not been answered, did not do their responsibility, such as covering intimate parts. This condition is supported by the result of the study conducted by Nurhidayah \& Hidayanti (2009), which found that the higher the fortitude, the higher the meaningfulness of life, and vice versa. In other words, there is a positive relationship between fortitude and meaningfulness of life.

The subjects of the study were Muslim early adult women. Early adulthood phase is the period where emotional tension. Agnew's (1992) study found that uncontrollable emotional tension will turn into negative emotion. Based on demographic data exhibited by Khairani \& Putri's (2011) result of the study, the highest level of emotional maturity is found in 24 years old women. This may be accounted for by Benokraitis's theory, as cited in Khairani \& Putri (2011), which states that the older age leads to more controlled and mature emotion. An individual's ability in addressing life conditions is highly influenced by emotion regulation ability.

During the process of achieving emotional maturity, many possibilities exist. Fail selfadjustment and unsolved problems such as job, marriage, or parental role may emotionally disturb individuals, which may cause them to have suicidal thoughts or attempt. In addition, women's self-adjustment during adulthood is more difficult than men's. In adulthood, women are more aware of religiosity than men are. With regard to religiosity, women directly feel its impact. According to Hendropuspito (1983), women show bigger loyalty in religious practice, are able to directly feel spiritual benefits such as spiritual serenity and able to accept religious values. Whereas men need rational basis before accepting and appreciating the value. In addition to select young adult women as the participants of the study, considering that suicide cases are sometimes caused by economic factor, this study also considers economic condition as another important part to answer the problem of the study, All subjects of the study were categorized as 'poor' according to BKKBN RI. 
Anggraeni's (2011) result of the study found that religiosity is significantly and positively associated with psychological well-being. In the same vein, Hamidah \& Gamal (2019) stated that there is a significant relationship between religiosity and psychological well-being in soldiers of Indonesian Army. The result of these studies shows that religiosity affects individuals' various life aspects. The present study aimed to depict the effect of poor adult women' religiosity on meaningfulness of life, this study can be used as a reference for the government or concerning institution to make right decisions regarding this issue. The result of this study is expected to contribute to the literature on positive positive psychology, particularly meaningfulness of life.

\section{METHODS}

Using causal design, the present study applied quantitative approach. Samples of the study were determined using Krejci-Morgan's table. 123 women were selected using cluster random sampling from the population of 180 women. The selected samples were women who met the criteria of poor according to National Family Planning Coordination Board (BKKBN $\mathrm{RI}$ ), which is categorized as prosperous family 1 . BKKBN RI's category of prosperous family 1 refers to a family who is only able to satisfy its basic needs, such as eating twice a day but are not able to fulfill higher needs such as psychological needs (e.g, to perform regular prayer, or to buy one new set of clothes a year. In this study, I developed meaningfulness of life scale and religiosity scale, these scales were tried out toward adult women who met the criteria of the study.

Meaningfulness of Life scale that had been tried out consists of 48 items. However, after the analysis, 17 items were removed, leaving 31 valid items. The validity test used correlation with the standard value of 0.3 based on corrected item-total correlation table in SPSS. The reliability test was done using Cronbach's Alpha, the result showed that meaningfulness of life scale's coefficient of reliability was 0.904 , meaning that the scale is reliable.

Another instrument used in this study was religiosity scale. This scale consisted of 48 items. After the try out and analysis, 9 items were removed. The removed items were those with value less than 0.3 based on corrected item-total correlation table in SPSS. The reliability test was done using Cronbach's Alpha, the result showed that religiosity scale's coefficient of reliability was 0.942 , meaning that the scale is reliable. The data were analyzed using simple linear regression. The use of multiple linear regression aims to find out the effect of religiosity on meaningfulness of life.

\section{RESULTS AND DISCUSSION}

The present study focuses on the effect of religiosity on poor adult women's meaningfulness of life. The result of the analysis is shown in Table 1.

\begin{tabular}{lccc}
\hline Variable & Mean & F & sig. \\
\hline Meaningfulness of Life & 113.18 & \multirow{2}{*}{55.59} & $<0.05$ \\
Religiosity & 99.99 & & \\
\hline
\end{tabular}

Table 1. The Effect of Religiosity on Meaningfulness of Life

As shown in Anova table, in significance level of 5\%, the $F_{\text {count }}$ was 55.659 with significance of $0.000<0.005$, meaning that the variance of independent variable's value is able to account the dependent variable. In other words, religiosity has linear relationship with meaningfulness of life. The result of this study showed that religiosity significantly affected poor adult women's meaningfulness of life in Gari Village.It possibly occurs because participants' religious knowledge is in line with the life meaning of poor adult women in Gari 
Village. It is in line with Amawidyati and Utami (2007) who found that an individual's strong religiosity may promote higher life satisfaction, higher personal happiness, lower traumatic event's negative effect, compared to those with lower level of religiosity.

Religiosity possesses five dimensions, namely, belief, prayer, internalization, experience, and religious understanding. In addition to religious understanding, in general, participants have faith, internalization, and positive religious experience. This study found that participants' low level of religiosity comes from their religious understanding. Religious knowledge serves as one of the factors causing participants to have low religiosity. It may be also caused by the participant's low educational background (most of them are elementary school or junior high school graduate), which prevents them from gaining adequate religious knowledge. However, the participants still highly believe in their religion and perform prayer well. The study conducted by Argyle (2002) found that religiosity helps an individual to maintain his/her mental health during adversity. Adequate level of religiosity allows individuals to survive life in accordance with the norms and values. In addition, participant's low religiosity may also be caused by lack of factors of religious maturity.

Religious maturity is one of individuals' desires to perfectly understand and apply their religious teachings. According to Reza (2015), an individual can be considered having religious maturity when they possess knowledge of religious values, understand, attempt to appreciate the religious practice, as well as apply the religious values in every activity. In line with previous statement, Alport, as cited in Subandi (2013), proposes six criteria that indicate mature religious life. One of them is to be heuristic, meaning that an individual realizes the limit in his/her religious life, thus making him/her to always attempt to improve his/her religious understanding and internalization. Two statements above explain that, when individuals possess religious maturity, they will always realize that they have deficiencies relating to religious matters, thus causing them to always learn to improve their religious knowledge. Clark \& Worthington (1990) argues that many adults do not have religious maturity, which is shown by religious life characteristics they bring since their childhood until adulthood, namely egocentric and ritualistic, superficial religious attitude. The tendency of egocentric is shown, for instance, when adult people pray only for themselves/ their close friends, while ritualistic, superficial religious attitude is shown by religious ritual that is done as a form of childhoo habit. An individual's religious maturity is also shown by his/her pursuit of religious perfection by increasing his/her religious understanding. This is supported by Steger, Oishi, \& Khasdan, (2009) who found that the search of purpose in life serves as the source of meaning in individuals' life.

Meaningfulness of life is one of individuals' need in order to have clear purpose in life. This is important because meaningfulness of life is one of the ways to attain happiness. Salikhova (2016) explains that meaningfulness of life lies in unconscious satisfaction, unconscious dissatisfaction, unconscious avoiding, conscious satisfaction, conscious dissatisfaction and conscious denial. Meaningfulness of life lies in different places and has different capacity between one individual and another, these differences will lead to the quality of a person's meaningfulness of life.

Meaningfulness of Life is deemed important and valuable, as well as providing special value for an individual, making it worthy to be used as short-term or long-term purpose in life. Meaningfulness of Life refers to understanding life as an achievement of a number of purposes through actively creating valuable matters (Frankl, 1992). In other words, meaningfulness of life can be viewed as the level of an individual's understanding of purpose attainment by doing attempts he/she considers valuable. Due to its importance, meaningfulness of life serves as one of triggers to encourage individuals living their life for having clear purpose in life. Even during adversity, meaningfulness of life still can be found, depending on how an individual attempts to get out of conditions making his/her life 
meaningless. To understand meaningfulness of life, it is important to know various aspects of meaningfulness of life as a reference in measuring meaningfulness of life of life.

Meaningfulness of life can be obtained through a set of processes and experiences. The way an individual achieve meaningfulness of life depends on how he/she can accept life and view that this life is meaningful. Willingness to have meaningful life depends on the individual's attempt in making meaningful life. In this study, various factors affecting an individual's meaningfulness of life follow experts' statements. These factors include the interaction of religiosity with human's life (Bronk et al., 2009; Davis \& Hicks, 2016; Valiullina, 2016), correlation between meaningful life and psychological state (Hicks et al., 2012; Salikhova, 2014), hope and the future priority (Kasler et al., 2012), cross-cultural difference in life meaning (Salikhova, 2014), and relationship between awareness and living together (Lightsey et al., 2014). It is predicted that linear condition found in this study is caused by many external factors we could not detect. However, we agree with these experts' statements on formulating effects of individual's meaningfulness of life.

Meaningfulness of life emerges in different characteristics. It is important to have references in determining characteristics of meaningfulness of life. The followings are the characteristics of individuals with meaningfulness of life according to Bastaman (1996) 1) Living life vigorously, 2) Having clear purpose in life, 3) Ability to feel the achieved progress, 4) Satisfaction toward self-activity, 5) Having creativity and innovation, 6) Being able to appreciate life, 7) Ability to realize life meaning, 8) Being able to love and be loved. Desire to find meaning and to have purposes or reasons in living the life are characteristics of meaningfulness of life.

Meaningfulness of life is affected by a number of factors. These factors can be categorized into internal and external factors (Bastaman, 2007). Internal factors refer to factors stemming from individual's self. These factors include self-discovery, positive act, being familiar with the environment, the deepening of values, prayer, and personal quality. External factors refer to factors affected by other things outside the individuals. These consist of material, social support, job, and close persons. Other factors that can also contribute to meaningfulness of life, according to Frankl (1992) are mindset, attitude, self-concept, prayer, experience, and culture. Both internal and external factors play roles in shaping an individual's meaningfulness of life. Based on two statements above, it could be concluded that factors of meaningfulness of life consist of internal and external factors. The former includes positive act, self-quality, prayer, attitude, and mindset, while the latter includes social support, job, material, experience, and culture. Prayer is a part of religiosity because it serves as the embodiment of individuals' faith in God, which helps individual to draw the life meaning.

This study also explains that an individual's meaningfulness of life can be achieved due to many factors, and religiosity is one of them. The result of this study has explained the role of religiosity in affecting meaningfulness of life from various perspectives. However, the analysis result of this study has not revealed other factors affecting an individual's meaningfulness of life. It is expected that future study can serves as the basis for deeper understanding.

\section{CONCLUSIONS}

This study concludes that there is a linear relationship between religiosity and meaningfulness of life, meaning that religiosity significantly affect poor adult women's meaningfulness of life. The result of this study depicts the effect of poor adult women' religiosity on meaningfulness of life, this study can be used as a reference for the government or concerning institution to make right decisions regarding this issue. It is important to internalize religiosity education in poor adult women participating in this study and also in 
community. It is expected that religiosity can bring more significant effect on meaningfulness of life.

\section{ACKNOWLEDGMENTS}

The author expresses their sincere thanks to everybody who was involved in conducting this study.

\section{AUTHOR CONTRIBUTION STATEMENTS}

All authors conduct the research and write the manuscript together. All authors have agreed with the final manuscript.

\section{REFERENCES}

Amawidyati, S. A. G., \& Utami, M. S. (2007). Religiusitas dan Psychological Well-Being pada Korban Gempa. Jurnal Psikologi, 34 (2), 164-176. https://doi.org/10.22146/jpsi.7095

Anggraeni, R. D. (2011). Hubungan antara Religiusitas dan Stres dengan Psychological Well Being pada Remaja Pondok Pesantren. Jurnal Psikologi Teori dan Terapan, 2 (1), 2945. Retrieved from Google Scholar

Argyle, M. (2002). The Psychology of Happiness. Routledge. Retrieved from Google Scholar Arista, D. (2017). Kebermaknaan Hidup dan Religiusitas pada Mantan Narapidana Kasus Pembunuhan (di Kabupaten Paser). Jurnal Psikoborneo, 5(3), 602-619. Retrieved from Google Scholar

Bastaman, H. D. (1996). Meraih Hidup Bermakna: Kisah Pribadi dengan Pengalaman Tragis. Jakarta: Paramadina. Retrieved from Google Scholar

Bastaman, H. D. (2007). Logoterapi : Psikologi untuk Menemukan Makna Hidup dan Meraih Hidup Bermakna. Jakarta: PT Raja Grafindo Persada. Retrieved from Google Scholar

Bronk, K. C., Hill, P. L., Lapsley, D. K., Talib, T. L., \& Finch, H. (2009). Purpose, Hope, and Life Satisfaction in Three Age Groups. The Journal of Positive Psychology, 4(6), 500 510. https://doi.org/10.1080/17439760903271439

Clark, C. A., \& Worthington, E. L., Jr. (1990). Family variables affecting the transmission of religious values from parents to adolescents: A review. In B. K. Barber \& B. C. Rollins (Eds.), Parent-adolescent relationships (167-191). University Press of America. Retrieved from Google Scholar

Davis, W. E., \& Hicks, J. A. (2016). Judgments of Meaning in Life, Religious Beliefs, and the Experience of Cognitive (Dis)Fluency. Journal of Personality, 84 (3), 291-305. https://doi.org/10.1111/jopy.12159

Frankl, V. E. (1992). Man's Search for Meaning: An Introduction to Logotherapy. Beacon Press. Retrieved from Google Scholar

Hamidah, T., \& Gamal, H. (2019). Hubungan Religiusitas dengan Psychological Well-being pada Anggota Satpamwal Denma Mabes TNI. Ikra-ith humaniora: Jurnal Sosial dan Humaniora, 3(2), 139-146. Retrieved from Google Scholar

Hayyu, A., \& Mulyana, O. P. (2015). Hubungan antara Dukungan Sosial dan Kebermaknaan Hidup pada Penyandang Tuna. Jurnal Psikologi Teori dan Terapan, 5 (2), 111-118. http://dx.doi.org/10.26740/jptt.v5n2.p111-118

Hendropuspito, O. C. (1983). Sosiologi Agama. Kanisius. Retrieved from Google Scholar

Hicks, J. A., Trent, J., Davis, W. E., \& King, L. A. (2012). Positive Affect, Meaning in Life, and Future Time Perspective: An Application of Socioemotional Selectivity Theory. Journal of Psychology and Aging, 27 (1), 181-189. https://doi/10.1037/a0023965 
Hudzaimah, N. H. (2019). Hubungan Antara Religiusitas Dan Dukungan Sosial Dengan Kebermaknaan Hidup Pada Wanita Dewasa Miskin Di Desa Gari Kecamatan Wonosari Kabupaten Gunungkidul (Master's Thesis, Universitas Ahmad Dahlan).

Kasler, J., Izenberg, P., Elias, M. J., \& White, G. (2012). Meaning in Life, Hope, and Priorities for the Future. Student Attitudes, 29-50. Retrieved from Google Scholar

Khairani, R., \& Putri, D. E. (2011). Kematangan Emosi Pada Pria dan Wanita yang Menikah Muda. Jurnal Psikologi, 1(2), 136-139. Retrieved from Google Scholar

Lightsey, O. R., Boyraz, G., Ervin, A., Rarey, E. B., Gharghani, G. G., \& Maxwell, D. (2014). Generalized Self-Efficacy, Positive Cognitions, and Negative Cognitions as Mediators of the Relationship between Conscientiousness and Meaning in Life. Canadian Journal of Behavioural Science, 46(3), 436-445. https://doi/10.1037/a0034022

Nurhidayah, S., \& Hidayanti, N. (2009). Hubungan Antara Ketabahan dan Locus of Control External dengan Kebermaknaan Hidup pada Istri yang Bekerja di Bagian Sewing pada PT. Bosaeng Jaya Bantar Gebang Bekasi. SOUL: Jurnal Ilmiah Psikologi, 2(2), 62-89. Retrieved from Google Scholar

Prasetyoningrum, A. K. (2012). Analisis Pengaruh Faktor Ekonomi dan Religiusitas terhadap Persepsi Supervisor dan Manajer Mengenai Independensi Dewan Pengawas Syari'ah (Studi Kasus pada Bank Syari'ah di Indonesia). Economica: Jurnal Ekonomi Islam, 2(2), 129-152. http://dx.doi.org/10.21580/economica.2012.2.2.853

Reza, I. F. (2015). Psikologi Agama: Peran Agama dalam Membentuk Perilaku Manusia. Palembang: NoerFikri Offset. Retrieved from Google Scholar

Agnew, R. (1992). Foundation for a general strain theory of crime and delinquency. Criminology, 30(1), 47-88. https://doi.org/10.1111/j.17459125.1992.tb01093.x

Salikhova, N. R. (2014). Correlation of meaningfulness of life to psychological time in personality. Asian Social Science, 10(19), 291-295. Retrieved from Google Scholar

Salikhova, N. R. (2016). Types of Meaningfulness of Life and Values of Future Teachers. International Journal of Environmental and Science Education, 11(8), 19431950. https://doi.org/10.12973/ijese.2016.568a

Steger, M. F., Oishi, S., \& Kashdan, T. B. (2009). Meaning in life across the life span: Levels and correlates of meaning in life from emerging adulthood to older adulthood. The Journal of Positive Psychology, 4(1), 43-52. https://doi.org/10.1080/17439760802303127

Subandi, M. A. (2013). Psikologi Agama dan Kesehatan Mental. Pustaka Pelajar. Retrieved from Google Scholar

Valiullina, M. E. (2016). Interrelation of Aggression with Reflexivity and World Image in Students of the Pedagogical Profile as an Opportunity to Improve Their Psychological Health. International Electronic Journal of Mathematics Education, 11(4), 559-568. Retrieved from Google Scholar

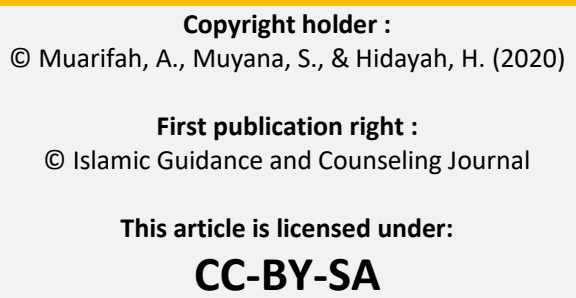

